\title{
Exposition of the Title
}

An exposition of the title prefixed to the Theological Elementation:

HERE BEGINS THE THEOLOGICAL ELEMENTATION OF PROCLUS, SON OF DIADOCHUS, SON OF LICIUS, THE PLATONIC PHILOSOPHER

This is the title prefixed to the present book. In it the four causes of the work, which are customarily sought out at the beginnings of books, are stated plainly. First there is the primary efficient cause, since it says: OF Proclus; the subjective material cause is touched upon in the phrase THEOLOGICAL ELEMENTATION, which also expresses the directive formal cause and the perfective final cause.

[A] Now, the philosopher Proclus was the author of this book. He was one of the greatest disciples of Plato, and so by prophetic insight he was named "Proclus", which means, as it were, "being esteemed from far and near" [procul cluens vel prope] or "being esteemed before" [ante cluens]; and "being esteemed" means "exceeding" or "surpassing". For, according to Papias, "I am esteemed" is the same as "I exceed" or "I surpass".

For Proclus exceeded by far [procul excellebat] all the followers of Plato and thus surpassed them all in ability [praepollebat], such that there emanated forth from him most of all, as it once had from Plotinus, "the very voice of Plato", which, as Augustine attests in Book III of Against the Academicians, ${ }^{2}$ "is the purest and most lucid in all of philosophy after the clouds of error have been cleared away" and all the coverings [integumentis], with which the first Platonists, and especially the Academicians, had concealed Plato's wisdom. For it was customary among them, as Cicero says and Augustine recounts in the same work, " 3 to conceal his doctrine and not reveal it to anyone, except to those who had lived with them up to old age". And thus Proclus, like Plotinus, as is recounted in the same text, "was deemed to be so similar" to Plato "that

1 Cf. Papias, Elementarium, s.v. “Cluere”, f. 34v.

2 Augustine, Contra Academicos, ed. W. Green (Turnhout: Brepols, 1970), III.18.41, p. 59, l. 41 p. $60,1.43$.

3 Augustine, Contra Academicos, III.20.43, p. 6o, l. 5-7.

4 Augustine, Contra Academicos, III.18.41, p. 6o, l. 43-46. 
one would have supposed that they lived at the same time; but since so many centuries had elapsed, one had to suppose that Plato was reborn in him".

Now, the excellence and surpassing ability of Proclus in comparison to the other Platonists is abundantly clear from the fact that, in the present book, he gave order to the theorems of Plato himself and explained what he had thus ordered in a most subtle way. Concerning these theorems, Eustratius says this in his commentary on Book I of the Ethics, chapter $4::^{5}$ "Plato passed on theorems concerning the first Good that are above contempt; indeed, they are magnificent conveyers of the soul into what is absolutely highest."

The excellence of Proclus also appears in the fact that, by ascending through the three motions that the divine Dionysius ascribes to angels and souls in chapter 4 of On the Divine Names, section $\mathrm{K}^{6}$ (which concerns the circular, direct, and oblique motions), he arrived at the knowledge of the highest Good, insofar as this is attainable to mortal humans under the guidance of the natural light of the intellect. As Dionysius treats them in that text, the definitions of these motions as they belong to the soul are as follows: 7 "Indeed, the motion of the soul is circular when it enters into itself from things external. It is a uniform convolution of its intellectual powers, granting inerrancy to the soul, as it were, in the form of a certain circle, first by gathering it, diffused in many externals, to itself, and then, with the soul having been given form, uniting it unitively with the united powers, and thus guiding it to the Beautiful and the Good, which is beyond all beings, and is one and the same, without beginning and without end. But the soul is moved obliquely insofar as it is illumined with divine cognitions according to its capacity, not intellectually and singularly, but rationally and diffusely, as it were, with mixed and transitory activities; and from exterior things as from certain variegated and manifold signs, it rises up to simple and united contemplations. But it moves by the direct motion when, neither entering into itself nor being moved by singular intellectuality (for this, as I have said, belongs to the circular motion), it proceeds to those things that are around it."

[B] That Proclus ascended by the circular motion, as I have claimed, is clear from his book On Fate and Providence, chapter 6, ${ }^{8}$ where he shows that reason, moved insofar as it is reason, looks to intrinsic reasons, and as such "evidently

5 Eustratius, In Ethicam Nicomacheam commentarius, translatio Roberti Grosseteste, ed. H.P.F. Mercken (Leiden: Brill, 1973), lib. I, c. 4, p. 68, l. 6o-62.

6 Cf. Dionysius, De divinis nominibus, 4.8-9 (Dionysiaca, vol. 1, p. 189-194; PG 3, 704D-705B); cf. Thomas of York, Sapientiale, lib. I, c. 6 (F f. 6rb).

7 Dionysius, De divinis nominibus, 4.9 (Dionysiaca, vol. 1, p. 190-193; PG 3, 705A-B).

8 Cf. Proclus, De providentia et fato, c. $6, \S 17$, p. 124, l. 20-24. 
distances itself from the senses, which it disdains, and is sequestered from pleasures and pains". And immediately thereafter he speaks about the uniform convolution of the soul's intellectual powers, saying: ${ }^{9}$ After the motion of the rational soul, I see another motion, better than the last, "with the lower powers now quieted and exhibiting none of the tumult that is usually found among the masses; by this motion, the soul is converted toward itself and sees its own substance and the powers existing in it, and the harmonic reasons from which it is made, and the many lives of which it is the plenitude, and it recollects that it is a rational world - indeed, an image of those things that are prior to it, from which it has come forth, but an exemplar of those which come after it, over which it presides."

And a little later in the same chapter, he writes:10 "After these two activities of this rational soul, as was said, we climb back up now to its highest intelligence, through which it actually sees its sister souls in the world" - and then, further on $^{11}$ - "and again, above all these souls, it sees the intellectual substances and orders" - and then ${ }^{12}$ - "and yet again prior to these it sees the monads of the gods themselves that are beyond intellect."

Boethius states the same thing concisely in Book v of On the Consolation of Philosophy, prose $4{ }^{13}$ while explaining the difference between intelligence and reason: "But there exists a higher eye of intelligence: for surpassing the boundary of the universe it views that simple Form by the pure apex of the mind."

So much for the first motion.

[C] That Proclus also ascended to the knowledge of God by the direct motion - »not by returning into himself, nor by proceeding with discursive reason from things that are outside, but departing from creatures as from certain tokens, images, or signs that are variegated and manifold in themselves, toward unitive reflections, not intelligibly but intellectually, not discursively but unitively, that is, not by the mind's oblique motion, but by its direct vision « ${ }^{14}-$ is clear in chapter 8 of the book mentioned above..$^{15}$ By this point Proclus has enumerated three of the soul's modes of cognition, that is, the opinionative, the scientific, and that which ascends up to the one and unhypothetical "through all the forms, so to speak - dividing some, analysing others, making

9 Proclus, De providentia et fato, c. $6, \S 18$, p. 124, 1. 2 - p. 126, 1. 8.

10 Proclus, De providentia et fato, c. 6, §19, p. 126, l. 1-3.

11 Proclus, De providentia et fato, c. 6, §19, p. 126, 1. 5-6.

12 Proclus, De providentia et fato, c. 6, §19, p. 126, l. 8-9.

13 Boethius, Consolatio philosophiae, lib. v, prosa 4, p. 149, 1. 86-88.

14 Thomas of York, Sapientiale, lib. I, c. 6 (F f. 6vb).

15 Cf. Proclus, De providentia et fato, c. 8, §27-29, p. 136, l. 1 - p. 138, 1. 15. 
the many from the one and the one from the many". Through this process the soul ascends to the principle of beings as such and "as far as the ascent of the instruction of the sciences reaches". Then he immediately adds: ${ }^{16}$ "There is yet a fourth mode that you must understand, and this is our simpler cognition that no longer uses methods such as analyses, syntheses, divisions, or demonstrations, but gazes upon beings by simple epiboles, meaning 'projections', and, so to speak, by antoptices, meaning 'per se visions'. Those who can achieve this mode of knowing praise it, referring to it now reverently as intellect and not as science. Or have you not heard that Aristotle in his books on demonstration in fact says something like this, that intellect in us is greater than all science, and that he defines it as that by which we know the terms? And that Plato in the Timaeus declares that intellect and science are modes of cognition in the soul that relate to beings? For science indeed seems to belong to the soul, insofar as the soul is cognition; whereas the intellect belongs to it insofar as the soul is an image of what is truly intellect. For the latter sees things intellectual, or rather being itself, through one epibole, as he says (meaning 'injection' or 'intuition'), and through contact with the things known; thinking itself, it beholds those beings within it, and because of that, it thinks both that it itself exists and that it is thinking, and that it at once thinks being and what it is itself. Therefore, imitating this as much as it can, the soul itself becomes intellect, running beyond science, abandoning the manifold methods with which it was formerly adorned, and raises its eyes to beings alone."

Shortly thereafter, ${ }^{17}$ Proclus discusses the cognition above intellect, which the theologians before Plato also divulged by calling it a truly divine frenzy: "For they claim that the one of the soul no longer arouses an intellectual power", but connects the one itself to the highest One, to which, "casting forth its one, the soul loves to be at peace, enclosing itself from cognitions, having been made silent, and keeping quiet with inward silence". Dionysius agrees with these points in chapter 7 of On the Divine Names section B and chapter 4, section N. ${ }^{18}$

So much for the direct motion.

[D] Proclus certainly also ascended by the oblique motion to the knowledge of the highest Good. This motion was proper to the philosophers and occurred »by a laborious investigation of the first Principle of all beings, by dividing, defining, using common principles, proceeding from the known to the unknown by discursive reason, ascending from the sensible to the intelligible,

16 Proclus, De providentia et fato, c. 8, §3०, p. 139, l. 1-21.

17 Cf. Proclus, De providentia et fato, c. 8, §31, p. 139, l. 1 - p. 140, l. 12.

18 Cf. Dionysius, De divinis nominibus, 7.1 (Dionysiaca vol. 1, p. 385-386; PG 3, 865C-868A) and 4.11 (Dionysiaca, vol. 1, p. 205-207; PG 3, 708D-709A). 
and tending from one thing to another among the intelligible, until it arrives to the ultimate ${ }^{19}$ as such. It is clear from the present book that Proclus accomplished this. For here he ascends to the highest by attending to the condition of the works, the governance of what is made, and the reconciliation of contraries. For these are the three ways by which the philosophers arrived at the knowledge of God by discursive reason.

»A person ascends by attending to the condition of the works, because, as Gundissalinus says in On the Creation of Heaven and Earth, ${ }^{20}$ "The ways to the creator are his works. When we diligently turn our attention to these, we are able to reach the understanding of any hidden thing of God whatsoever"; indeed, "the crafting of the world is the projection of the invisible things of God", as Dionysius says in the Letter to Titus. ${ }^{21}{ }^{22}$ The author ascended along this path, both by the investigation of the many and the one, and by the investigation of productive principles and what is produced, as is clear from the first 12 elements. $^{23}$

»A person also ascends to God from the governance of what is made, just as Cicero shows in Book II of On the Nature of the Gods, chapter $5 .{ }^{24}$ His words are summarised as follows: the world exists and is ruled by reason; but the reason ruling the world is beyond the world and not from the world; therefore, there is some reason that rules the world, which we call God or his providence. «25 The author also proceeded along this path in this book, as is clear from proposition 120 and many that follow, ${ }^{26}$ and especially in the book On Providence, ${ }^{27}$ where ten questions concerning providence are resolved.

A person also ascends to the knowledge of God from the reconciliation of the contraries that are in the world, Plato made clear in the Timaeus. ${ }^{28}$ In this work, Plato himself pursued the cognition of God and the highest Artificer by all three paths. Boethius is also in agreement with him in Book III of On the Consolation, prose 12: ${ }^{29}$ "The world could hardly have come together from such

\footnotetext{
19 Thomas of York, Sapientiale, lib. I, c. 6 (F f. 6vb).

$20 \quad$ Dominicus Gundissalinus, De processione mundi, p. 2, l. 1-3.

21 Dionysius, Epistulae, IX.2 (Dionysiaca, vol. 1, p. 642; PG 3, 1108B).

22 Cf. Thomas of York, Sapientiale, lib. I, c. 7 (F f. $7 \mathrm{va}$ ).

23 Proclus, Elementatio theologica, props 1-12, p. 3, l.1 - p. 9, l. 19.

24 Cf. Cicero, De natura deorum, II.6.16-II.7.19, p. 55, l. 11 - p. 57, l. 4.

25 Cf. Thomas of York, Sapientiale, lib. I, c. 7 (F f. 8ra).

26 Cf. Proclus, Elementatio theologica, prop. 120, p. 6o, l. 1-13.

27 Proclus, De decem dubitationibus circa providentiam.

28 Cf. Plato, Timaeus, 27d-29d, p. 20, l. 15 - p. 22, l. 14 et seqq.

29 Boethius, Consolatio philosophiae, lib. III, prosa 12, p. 92, 1. 14-25; cf. Thomas of York, Sapientiale, lib. I, c. 7 (F f. 8rb).
} 
diverse parts into one form, were there not one God, who joins such diversity together. But this diversity of natures, once brought together, is discordant with itself, and would dissociate and tear apart, were there not One who sustains what he has brought together. Such a defined order of nature, moreover, would not have proceeded forth, nor would the things thus arranged unfold in local motions, times, effective causes, spaces, and qualities, were there not One who, remaining himself, arranged these varieties of change. This, whatever this is, by which the things that are made abide and are set in motion, I call 'God', using the word that everybody uses." That Proclus proceeded along this path is clear from proposition $2 \mathrm{O}^{30}$ and those that follow, and in many other places in the present book, and in his book On the Existence of Evils. ${ }^{31}$

From the foregoing, the excellence and surpassing ability of this author, Proclus, are abundantly clear.

[E] Now, in the title there follows: OF DIADOC HUs, OF LYCIUs. These might be Proclus' first name and surname, such that he would have had three names; or, as seems more likely to me, these were the first names of his ancestors, which he prefixed to the title of his book following the ancient custom. For the ancients not only set down their own names in their titles and the names of their parents, but also their ancestors' first names, last names, and epithets, as is clear from the books of that most brilliant man, Boethius. ${ }^{32}$ For this reason Proclus also adds both his school and his profession: "the Platonic philosopher".

Therefore, he states: OF DIADochus, meaning "son of". Now Diadochus means "what is taught" or "what teaches generously", for dia means "generous",33 or it derives from dia and doxa, which means "glory"34 - meaning, as it were, "generous glory" or "generously glorifying" or "glorious and generous". For there is nothing (to say nothing of his descendant) more generous than wisdom itself, in whose possession Diadochus glorified.

Wisdom's generosity appears from its source, the height of its nobility, and the multitude of its generous effects that it produces in those who have it.

»The source of wisdom is most high because "the fount of wisdom is the Word of God in the highest",35 not only the divine wisdom of the orthodox or the faithful, but even of the Gentile philosophers, as is clear from Plato's

30 Cf. Proclus, Elementatio theologica, prop. 20, p. 13, l. 1 - p. 14, l. 31.

31 Proclus, De malorum subsistentia.

32 Cf. Boethius, Consolatio philosophiae, titulus, p. 3; id., De Trinitate, ed. C. Moreschini, prologus, p. 165; id., Utrum Pater et Filius, ed. C. Moreschini, p. 182.

33 Cf. Papias, Elementarium, s.v. "Dia”, f. 46r.

34 Cf. Huguccio of Pisa, Derivationes, s.v. "Doxa” (D88, p. 348, §1).

35 Ecclesiasticus 1:5. 
propositions, which Augustine recounts. ${ }^{36}$ For in Book VIII of On the City of God, chapter $33^{37}$ he says that God is "the light of all", and in chapter $4,{ }^{38}$ that God is "the enlightener of truth" and "the reason of thinking", without which "no teaching instructs". In Book IX, chapter $25,{ }^{39}$ he says that God is "the giver of intelligence". And in Book I of the Soliloquies, near the beginning, he writes:40 "God, the Father of truth, the Father of wisdom, ... the Father of intelligible light"; and below:41 "God of truth, in whom and from whom and through whom are true all things that are true; God of wisdom, in whom and from whom and through whom are wise all who are wise"; and below:42 "God, intelligible light, in whom and from whom and through whom shine intelligibly all things that shine intelligibly."

The height of the nobility of wisdom is clear »because it is desirable in itself, as Aristotle shows in Book VI of the Ethics, chapter $15{ }^{43}$ where he says that wisdom and prudence are desirable in themselves: "now, what is desirable in itself is free and perfect through itself, serving nothing else, governing the order through itself and holding dominion within itself", as the Commentator explains on the same text. ${ }^{44}$

If we now turn the mind's gaze toward the effects of wisdom, it becomes clear that wisdom is also generous. In those who possess it, wisdom, with regard to evil things, is fugitive of vice, sanative of sickness or allative of health, conducive to a place far from disturbances and passions, and contemptive of this life and this world; but with respect to the good, wisdom is formative of life, inculcative of the virtues, perfective of the soul, consummative of creation, elongative from our animal nature, impletive with longings, introductive of delight, and operative of beatitude. $\aleph^{45} »$ And so Cicero, in Book V of the

\footnotetext{
36 Cf. Thomas of York, Sapientiale, lib. I, c. 1 (F f. rrb).

37 Augustine, De civitate Dei, viII.4, p. 220, 1. 35-36; apud Thomas of York, Sapientiale, lib. I, c. 16 (F f. 2ora).

38 Cf. Augustine, De civitate Dei, viII.4, p. 220, l. 5o-6o; apud Thomas of York, Sapientiale, lib. I, c. 16 (F f. 2orb).

39 Augustine, De civitate Dei, IX.25, p. 334, l. 12; apud Thomas of York, Sapientiale, lib. I, c. 16 (F f. 2orb).

40 Augustine, Soliloquia, I.1.2 (PL 32, 870).

41 Augustine, Soliloquia, I.1.3 (PL 32, 870).

42 Augustine, Soliloquia, I.1.3 (PL 32, 870); apud Thomas of York, Sapientiale, lib. I, c. 16 (F f. 2ova).

43 Cf. Aristotle, Ethica Nicomachea, vi.13, 1144a1-2.

44 Eustratius, In Ethicam Nicomacheam commentarius, lib. VI, c. 15 (Ms Vaticano [Città del], Biblioteca Apostolica Vaticana, Vat. lat. 2171, f. 129ra). Cf. Thomas of York, Sapientiale, lib. I, c. 1 (F f. 1rb).
} 
Tusculan Disputations, chapter $5,{ }^{46}$ exclaims: "O Philosophy, the guide of life, $\mathrm{O}$ discoverer and cultivator of virtue, and expeller of vices, what would we, and indeed the whole life of humankind, be without you?" And below: ${ }^{47}$ "You have been the discoverer of laws, the mistress of morals and discipline. We take refuge in you; from you we implore succour. We, who formerly devoted our greater part to you, now give ourselves over entirely. For a day spent well in your precepts is preferable to perpetuity and immortality without them. Whose succour do we need more than yours, you who have granted to us tranquillity of life and taken from us the fear of death?" " 48

Therefore, from the explanation of his name, one can gather the nature and greatness of the philosopher Diadochus, whose name is inscribed in the title.

[F] Then there follows in this title: OF LICIUS, meaning "son of". Licius was the grandfather of Proclus. Now, Apollo was also called Licius, ${ }^{49}$ and Apollo stands for the "sun", 50 which according to the Gentiles of old was the god of wisdom; ${ }^{51}$ or, according to Papias, ${ }^{52}$ "Licius" comes from lichios, meaning the luminescent purple stone in lanterns that shines forth in splendour, and for this reason a lantern is called a lichios.

And so, one can surmise from his name that Licius was, in a manner of speaking, a god or the sun, and the fontal, overflowing abundance of wisdom, with the ray of his wisdom passing over everything. For among the sages of his time it is likely that he shone like a radiant lantern. Otherwise, it would have been inappropriate for Proclus to inscribe this at the beginning of his book, »unless those to come could obtain immense benefits from the splendour of his wisdom. For it is quite possible that, from the illumination of wisdom, many devoted themselves to the exercise of their own intellect and, consequently, to gather kindred spirits, to educate them in the preambles to wisdom, to dissolve doubts, to consider the height of wisdom, and to apprehend the deeper truth. ${ }^{53}$

[G] Next in the title we have the sect to which Proclus belonged: OF THE PLATONIST.

\footnotetext{
46 Cicero, Tusculanae disputationes, v.2.5, p. 406, l. 3-5.

47 Cicero, Tusculanae disputationes, v.2.5-6, p. 406, 1. 9-16.

48 Cf. Thomas of York, Sapientiale, lib. I, c. 1 (F f. 1vb-2ra).

49 Cf. Papias, Elementarium, s.v. “Licium", f. 91r.

50 Cf. Papias, Elementarium, s.v. "Apollo", f. 13r; Isidore of Seville, Etymologiarum, vol. 1, lib. VIII, c. 11, §53.

51 Cf. Augustine, De ordine, ed. W. Green (Turnhout: Brepols, 1970), I.4.10, p. 94, l. 22-26.

52 Cf. Papias, Elementarium, s.v. “Luchinus", f. gir.

53 Cf. Thomas of York, Sapientiale, lib. I, c. 3 (F f. 3ra-b).
} 
Now, just as Augustine says in Book VIII of On the City of God, chapter 1, ${ }^{54}$ "there is no one, who has even a meagre acquaintance with such things, who does not know about those philosophers called Platonists, who derive their name from the learned Plato. Therefore, concerning this Plato, I will touch briefly upon those things I deem necessary to the present question, first by recalling his predecessors in this kind of literature."

And he says in chapter 2 of the same book: 55 "As far as Greek literature is concerned (which among the nations is the more celebrated), two schools of philosophers are known to us: the one is called Italic, coming from that part of Italy once known as Magna Graeca; the other is Ionian, coming from those lands now called Greece. To the Italic school belonged the authority of Pythagoras of Samos, from whom the very name of philosophy takes its origin; ... the founder of the Ionic school was Thales the Milesian; ... Anaximander was his pupil and succeeded him; ... Anaximander left Anaximenes as his disciple and successor; ... and Anaxagoras was his pupil" along with Diogenes. Succeeding Anaxagoras was Archelaus, whose disciple Socrates is said to have been, and Socrates was the master of Plato - which is why I have briefly summarised these passages from Augustine's City of God.

"Therefore, having acquired such illustrious renown by his life and death, Socrates left behind many followers of his philosophy", as Augustine says in chapter $3 \cdot{ }^{56}$ "But among the disciples of Socrates", as we read in chapter $4,{ }^{57}$ "Plato shone with a most surpassing glory and, not unjustly, he eclipsed the others in every way."

Plato, as is said in Book III of Against the Academicians, ${ }^{58}$ "was the wisest and most learned man of his times, and he spoke in such a way that whatever he said became important, and he spoke of such things that, in whatever way he said them, they never became unimportant". And later: ${ }^{59}$ "In this way, he added to the Socratic charm and subtly (which Socrates possessed in ethical doctrine), an expertise in things natural and divine ... and is said to have devised the perfect practice of philosophy", "which is arranged in three parts", as we saw already from On the City of God, ${ }^{60}$ "one part is moral, which above all

54 Augustine, De civitate Dei, viII.1, p. 217, 1. 34-39.

55 Cf. Augustine, De civitate Dei, viri.2, p. 217, l. 1 - p. 218, l. 48.

56 Augustine, De civitate Dei, viII.3, p. 219, l. 31-32.

57 Augustine, De civitate Dei, viII.4, p. 219, l. 1-3.

$5^{8}$ Augustine, Contra Academicos, III.17.37, p. 57, l. 6-9.

59 Augustine, Contra Academicos, III.17.37, p. 57, l. 15-21.

6o Augustine, De civitate Dei, vilı.4, p. 220, 1. 25-28; cf. Berthold of Moosburg, Prol. 20, n. 242-246. 
concerns action, the other part natural, which is considered by contemplation, and the third part is rational, by which the true is separated from the false". And later:61 "But as to Plato's views about these parts taken altogether or about each singly, that is, what he understood to be the end of all actions, the cause of all natures, and the light of all reasons - I believe it would take a long time to explain these, and I do not wish to make rash assertions." Thus Augustine.

Therefore, from this same Plato, whom Labeo calls a demigod, ${ }^{62}$ the philosophers mentioned already, namely, Proclus and his ancestors Diadochus and Licius, are called Platonists in order to distinguish themselves from the Peripatetics and Cynics. For, according to Augustine in Book III of Against the Academicians, ${ }^{63}$ "Nowadays we scarcely see any philosophers who are not Cynics, Peripatetics, or Platonists. The Cynics are especially popular because a certain liberty of life or licentiousness brings them delight. Since, however, philosophy touches on learning, teaching, and morals, by which the soul is cared for," we have in the title: OF THE PHILOSOPHER.

$[\mathrm{H}]$ The word "philosophy", as was said, ${ }^{64}$ comes from Pythagoras. For "when asked what he professed, he responded truly, saying that he was 'a philosopher', meaning a lover of wisdom, since it seemed supremely arrogant to claim that one was wise. And so, from that point on, it pleased those who came thereafter that, no matter how much a person seemed to excel in wisdom, either to himself or to others, he would not be called anything except 'a philosopher', as Isidore writes in Book VIII of the Etymologies. ${ }^{65}$

Now Cicero writes, in Book v of the Tusculan Disputations, ${ }^{66}$ that seven philosophers in antiquity "were and were called sophi by the Greeks and, by us, 'the wise'". Below he adds: 67 "their name was preserved down to the age of Pythagoras who, as Heraclides Ponticus (a most learned man and a student of Plato) reports, is said to have gone to Phlius and to have learnedly and regularly discoursed on certain subjects with Leon, the prince of the Phliusians. When Leon, admiring his genius and eloquence, asked him what art he professed above all else, he answered that he in fact knew no art but was rather a philosopher. Leon, admiring the novelty of the name, asked him who the philosophers were and what distinguished them from others. Pythagoras then replied ..., ,

61 Augustine, De civitate Dei, viII.4, p. 220, 1. 33-38.

62 Cf. Augustine, De civitate Dei, viII.13, p. 230, l. 31-32.

63 Augustine, Contra Academicos, III.19.42, p. 6o, l. 1-5.

64 Berthold of Moosburg, Expositio tituli G, n. 55 .

65 Isidore of Seville, Etymologiarum, vol. 1, lib. vinI, c. 6, §2-3.

66 Cicero, Tusculanae disputationes, v.3.7, p. 407, l. 7-9.

67 Cicero, Tusculanae disputationes, v.3.8-9, p. 407, l. 19 - p. 408, l. 3. 
and below: 68 "those who hold all other pursuits as nothing, and studiously look into the nature of things - these people call themselves zealous for wisdom, that is, philosophers; and just as there [that is, in sport,] one is freest when one is a spectator, appropriating nothing for oneself, so too in life, the contemplation and knowledge of things surpass all other pursuits by far." Pythagoras also gives the example of the marketplace. ${ }^{69}$ "Pythagoras not only coined the name 'philosophy', but also magnified the thing itself." ${ }^{\prime 0}$ Thus Cicero.

And so, from the foregoing, the identity of the author of this book, the sect to which he belonged, and his profession, have all been made clear.

[I] There follows theOLOGICAL ELEMENTATION, which expresses the material, the formal, and the final cause of the book.

It expresses the subjective material cause in that the book, through the ordering of elements, treats the divine Good according to the order of natural providence. For this reason, it is called an "elementation" [elementatio], and not of just any kind, but "theological", to distinguish it from the Physical Elementation ${ }^{71}$ which this author is also said to have produced. In these two words the matter and subject are touched on most succinctly.

It touches on its matter, because the elements are, so to speak, the hylements $^{72}$ or the propositions, out of which this book is constructed and made whole. If they are taken in themselves and according to their own notion, they possess only the mode of matter with respect to this wisdom itself, and they contribute to its wholeness; "the mode of matter", I say, which carries the notion of a principle or an element, insofar as from them, together with the form, as from an intrinsic principle, as it were, the substance of the composite thing is constituted. For just as grammar has letters or elements for its material, from which it is brought together into a whole, and just as the Arithmetic of Jordan, ${ }^{73}$ the Geometry of Euclid, ${ }^{74}$ the Optics of Peckham, ${ }^{75}$ and certain other sciences, have hylementary propositions, so too this book has 211 elements, which are the principles of demonstration in this philosophy.

\footnotetext{
68 Cicero, Tusculanae disputationes, v.3.9, p. 408, l. 14-20.

69 Cf. Cicero, Tusculanae disputationes, v.3.9, p. 408, 1. 3-14.

70 Cicero, Tusculanae disputationes, v.3.10, p. 408, 1. 21-22.

71 Proclus, Elementatio physica, ed. H. Boese, Die mittelalterliche Übersetzung der Stoicheiosis physike des Proclus (Berlin: Akademie-Verlag, 1958).

72 Cf. Huguccio of Pisa, Derivationes, s.v. "Yle” (I45, p. 605, §3).

73 Jordan of Nemi, Arithmetica.

74 Euclid, Elementa.

75 John Peckham, Perspectiva communis.
} 
Aristotle alludes to this meaning of "element" in Book v of the Metaphysics, ${ }^{76}$ where he discusses the several senses of the term: "the elements of geometrical diagrams" and the elements of demonstrations all "are called 'elements' in a similar sense". What the Commentator explains about this passage can be summarised as follows: »They are called "elements" in a similar sense and in accordance with the same notion. But the first composite parts of geometrical diagrams, meaning those figures depicted in extension, are called "elements" in that they are composite parts relating only to position and are "parts from the whole" or "universal parts". But if what is meant is rather "an intrinsic element" by virtue of some power, then this denotes the "elements" of demonstrations, according to the notion of element introduced above. Now, the first demonstrations of all, to which none are prior, and which exist in many demonstrations that follow them due to their power, are called "the elements of demonstrations". Now, although these first demonstrations exist in the consequent demonstrations through their power, they also exist in them in some mode according to their substance: for, when dealing with a subject and a predicate, the first demonstration is implicated in the second, and so on, where the prior is always in the consequent according to the order of theorems. Postulates, hypotheses, and definitions are the elements of the first demonstrations in this way, and certain propositions are the truest "elements" of the conclusions « ${ }^{77}$ and, consequently, are the matter.

These theological elements are also the subject insofar as they include that which exists as something in act, in that it has the property of a subject. The act of consideration is concerned with the properties and attributes of this subject, which has a common notion by virtue of an analogical attribution to one first term, and to this first term the notion of a subject primarily belongs.

»This entire book treats the universe of divine things according to its procession from the highest Good and its return into the Good, according to the order and the proper intrinsic modes of the divine things themselves. These modes are placed in them by what is primarily divine or divine according to cause. This book treats this universe according to the order of natural providence, and not presently according to the order of voluntary providence (following the distinction made by Augustine in Book VIII of The Literal Commentary on Genesis).${ }^{78}$ It is necessary that everything treated here should agree in a single

${ }_{76}$ Aristotle, Metaphysica, v.3, 1014a35-37.

77 Cf. Albert the Great, Metaphysica, lib. v, tr. 1, c. 4, p. 217, l. 8-26; cf. Averroes, Metaphysica, ed. R. Ponzalli, Averrois in librum $V(\Delta)$ Metaphysicorum Aristotelis commentarius (Bern: Francke, 1971), lib. v, comm. 4, p. 86, l. 78 - p. 87, l. 88. 
notion of a subject, by virtue of which this philosophy itself is a single science. That subject is called, and indeed is, the divine good, which belongs to the first principle of all simply, absolutely, and causally or primarily, but to the other goods, namely the divine according to essence and the divine according to participation, attributively in relation to the first. This attribution occurs according to the modes distinguished by Averroes while commenting on the beginning of Book IV of the Metaphysics: ${ }^{79}$ namely, in relation to the primary efficient cause, in relation to the ultimate end, and also in the relation of accidents to their subject. « ${ }^{80}$ For God, who is the highest Good, is not only "the principle without principle, the process without variation, the end without end", as is said in rule 7 from Trismegistus, ${ }^{81}$ but indeed "God" is also that, "in comparison with whom substance is an accident, and an accident is nothing at all", as we read in rule 6 of the same text. ${ }^{82}$ Now, Hermes means that any substance is an accident by virtue of its dependency on the First, to whom alone the notion of a subject belongs - not as it belongs to beings existing in passive potency, but as the active potency by which he, who made the universes, sustains all things. Avicebron uses the term "accident" in this sense in Book III of the Fount of Life, chapters 36 and $54 .{ }^{83}$

From this it is clear that the subject of this book is the divine good within the order of natural providence, and this is expressed by the title THEOLOGICAL ELEMENTATION.

$[\mathrm{K}]$ In the same phrase, but taken under another notion, one finds expressed the book's directive formal aspect or the formal cause. For the form of proceeding in this book is through the coordination and separation of theorems or elements, which are, so to speak, elevatements or elaboratements ${ }^{84}$ because they elevate and cultivate the mind. These are the rules of this most divine philosophy; and it is also by virtue of these that it is called an "elementation", just as Varro calls grammar "letteration", according to Isidore. ${ }^{85}$

79 Cf. Averroes, Commentaria in libros Metaphysicorum Aristotelis (Venezia: Junta, 1562), lib. IV, comm. 2, f. 65 rF-vI.

8o Cf. Dietrich of Freiberg, De subiecto theologiae, ed. L. Sturlese, Opera omnia, vol. 3. Schriften zur Naturphilosophie und Metaphysik (Hamburg: Meiner, 1983), 3·5-6, p. 281, 1. $69-84$.

81 Hermes Latinus, Liber XXIV philosophorum, maxim 7, p. 13, l. 1-2.

82 Hermes Latinus, Liber XXIV philosophorum, maxim 6, p. 12, l. 1-2.

83 Cf. Avicebron, Fons vitae, ex Arabico in Latinum translatus abJohanne Hispano et Dominico Gundissalino, ed. C. Baeumker, 2 vols (Münster i.W.: Aschendorff, 1892-1895), vol. 1, lib. III, c. 36, p. 161, l. 14 - p. 162, l. 10; lib. III, c. 54, p. 199, l. 8-17.

84 Cf. Papias, Elementarium, s.v. "Elementum", f. 52r; Huguccio of Pisa, Derivationes, s.v. "Yle" (I45, p. 605, §4-5).

85 Cf. Isidore of Seville, Etymologiarum, vol. 1, lib. I, c. 3, §1. 
For every science uses the rules by which it is upheld like its own foundations, as Alan writes in the prologue of On the Rules of Theology, ${ }^{86}$ so that dialectic has maxims, "rhetoric has commonplaces, ethics has general teachings, physics has aphorisms, arithmetic has aporismata, meaning 'subtle rules', music has axioms, meaning "measures", geometry has theorems, meaning "speculations", and astronomy has excellences. In the same way, this philosophy, the most excellent, most divine, and most difficult of all sciences, has rules that are "exceedingly more obscure and subtler than the other" rules of other sciences, as is said in the same text. ${ }^{87}$ "Although complete necessity holds sway over the other rules, since the regular course of nature is governed by regularity alone, the necessity of theological rules is nevertheless absolute and unshakeable, because they produce conviction about what cannot be changed by action or by nature. And so, because of their immutable necessity and their glorious subtlety, they are almost fittingly called 'glorious paradoxes' by certain philosophers", or "enigmas" because of their obscurity, or "marquetries" because of their intrinsic splendour, or "hebdomads" because of their dignity. ${ }^{88}$

But the author calls them "theological elements", meaning "propositions", in which there is a discourse on the divine or on God, who is both the most divine and the most difficult to attain.

"Most divine", as Trismegistus says to Asclepius in On Hellera ${ }^{89}$ which means "On the God of gods" (where he establishes that, of all discourses inspired by divine obligation, a discourse on the God of gods is more divine in religious devotion), stating, "if you will be found to understand it, your whole mind will be filled with all goods". It is also "most difficult", and for this reason Trismegistus in the same text compares the discourse to a torrent: 90 "An account of divinity ... is most similar to a torrent of a river running from on high, sweeping and churning, such that it rushes on ahead of our attention, not only as we listen but also as we speak about it".

Thus it follows that not only the teacher but even the auditor must be a divine and attentive person.

"A divine person" because, in light of what Trismegistus says in the same text, ${ }^{91}$ "an account of divinity is to be known through the divine concentration

86 Cf. Alan of Lille, Regulae caelestis iuris, ed. N. Häring, in Archives d'histoire doctrinale et littéraire du Moyen Âge 48(1981), prologue, §1, p. 121.

87 Cf. Alan of Lille, Regulae caelestis iuris, prologue, §1-5, p. 121-122.

88 Cf. Alan of Lille, Regulae caelestis iuris, prologue, §5-6, p. 122.

89 Asclepius, c. 1, p. 39, l. 4-5.

90 Asclepius, c. 3, p. 41, l. 19-23.

91 Asclepius, c. 3, p. 41, l. 19-20. 
of awareness". For this is true philosophy: the assiduous inquiry into the knowledge of divinity. As Trismegistus says there, ${ }^{92}$ philosophy consists "only in repeated contemplation and the holy reverence with which one must know divinity".«93 "An attentive person", because of the elementation, extension, or coordination of the theological elements themselves; for to the extent that they contain a loftier meaning, so they require a more attentive and skilful auditor. Therefore, they are not to be expounded to fleshly or even to spiritual people, as is clear from the parable that Rabbi Moses sets down on this matter in chapter $182,{ }^{94}$ but only to intellectual people, »who, by a more rigorous inquiry, are attentive and perspicacious in the apex of the mind, and are less carried away by the fickleness of praise than attracted by the most longed-for, unveiled image of truth itself. Only to these worthy people should the worthiness of wisdom contained in this Theological Elementation be uncovered. And so are they led into these theorems as into a certain byway that is beyond the common path of reasonings. $\aleph^{95}$

Now, I say "beyond the common path of reasonings" because, as Boethius states near the beginning of On the Trinity: ${ }^{96}$ "In physics one must apply oneself rationally, in mathematics scientifically, and in theology intellectually, not being led astray by imaginings, but rather by looking into the Form itself, which is a true form and not an image." For the intentions of the Theological Elementation diverge from those of all other sciences such that »one cannot find discourses akin to them with which they could be easily explained «.97

From the foregoing one can grasp succinctly both the form or mode of proceeding in this book and the reason for its name, Theological Elementation, which is imputed from the form. Moreover, one can understand why it is not called "First Philosophy" or "Metaphysics", "On the Pure Good", "On the Light of Lights", "On the Cause of Causes", or "On the Flowers of Divine Things", as others $^{98}$ - who all treated similar material, but completely unlike the present author - bothered to call their works.

\footnotetext{
92 Asclepius, c. 12, p. 52, l. 2-4.

93 Cf. Thomas of York, Sapientiale, lib. I, c. 5 (F f. 5 va).

94 Cf. Moses Maimonides, Dux seu director dubitantium aut perplexorum, lib. III, c. 52, f. 109v-112r; cf. Thomas of York, Sapientiale, lib. I, c. 3 (F f. 4 ra).

95 Cf. Gilbert of Poitiers, Expositio in Boecii librum de bonorum ebdomade, ed. N. Häring, The Commentaries on Boethius by Gilbert of Poitiers (Toronto: Pontifical Institute of Medieval Studies, 1966), prologue, $\$ 7$, p. 184, l. 32-38.

96 Boethius, De Trinitate, c. 2, p. 169, 1. 78-82.

97 Cf. Gilbert of Poitiers, Expositio in Boecii librum de bonorum ebdomade, prologue, §8, p. 184, l. $39-45$.

98 Cf. Albert the Great, De causis et processu universitatis a prima causa, ed. W. Fauser (Münster i.W.: Aschendorff, 1993), lib. II, tr. 1, c. 1, p. 59, l. 7 - p. 61, l. 68.
} 
[L] Finally, the name THEOLOGICAL ELEMENTATION expresses the perfective final aspect or final cause. In this sense, "theological elementation", meaning "of divine reason", connotes a ladder ascending from the divine according to participation to the divine according to essence, and through this to the primarily divine, the divine according to cause, who is to be contemplated. The contemplation of this divinity makes the contemplator not only blessed, by pursuing "the perfect condition that is brought about by the collection of all goods", 99 but even god.

For, as Boethius says in Book III of On the Consolation, prose 10,100 "since it is obvious that they become blessed by acquiring beatitude, and by acquiring justice they become just, and by acquiring wisdom they become wise, so by a similar argument it follows necessarily that by acquiring divinity they become gods. Therefore, everyone who is in bliss is god; certainly, God is one by nature, but nothing prevents there being as many gods as you please by participation."

Now, this ladder ascending through deified reason to the divine reason according to cause seems to be implied by the allegory [integumentum], with which Lady Philosophy's embroidered garment is described using two letters, the Greek pi and theta, as we have it from Boethius in Book I of On the Consolation, prose $1 .{ }^{101}$ Having described Philosophy's countenance, expression, complexion, strength, age, and height, he describes her garment:102 "Her robes were fashioned perfectly with the finest threads, the most delicate artistry, and imperishable materials, which, as I would later learn from her, she wove herself." And below:103 "On the hem at the bottom one could discern a woven Greek $p i$, and at the top a theta, and between the two letters there seemed to be steps emblazoned as a ladder, forming an ascent from the lower to the higher letter."

Now what are meant by these robes if not the sciences? And, among the sciences, this one is the worthiest. Seneca points out its difference from every other human science in Book I of On Natural Questions, chapter 1:104 "the difference between philosophy ... and the other arts is as great as that ... between the part of philosophy concerned with humans and the part concerned with gods: the latter is higher and more spirited ... In short, the difference between

99 Boethius, Consolatio philosophiae, lib. III, prosa 2, p. 6o, l. 10-11.

100 Boethius, Consolatio philosophiae, lib. III, prosa 10, p. 83, l. 8o - p. 84, l. 86.

101 Cf. Boethius, Consolatio philosophiae, lib. I, prosa 1, p. 4, l. 1- p. 5, 1. 12.

102 Boethius, Consolatio philosophiae, lib. I, prosa 1, p. 5, l. 12-15.

103 Boethius, Consolatio philosophiae, lib. I, prosa 1, p. 5, 1.17-21.

104 Seneca, Naturalium quaestionum libros, ed. H. Hine (Leipzig: Teubner, 1996), lib. I, §1, p. 1, 1. 5 - p. 2, 1. 17; apud Thomas of York, Sapientiale, lib. I, c. 5 (F f. 5 va). 
the two is as great as that between God and human beings: the one teaches us what is to be done on earth; the other, what is to be done in heaven; the one dispels our wrongdoings and casts the light in, with which the uncertainties of life can be discerned; the other goes beyond the darkness in which we wallow and guides us, standing upright, out of the shadows, and leads us to the light's source."

And so, this science is denoted by the theta sewn on the upper hem of Philosophy's robes. For it consists in contemplating not just any object, but the highest Good, which is the end of all desires because, as Plato says, as Augustine recounts in Book VIII of On the City of God, chapter $4,{ }^{105}$ it is the end of all actions, the cause of all natures, and the light of all reasons.

"For if the human being is constituted in such a way that, through what surpasses everything in him, he may attain unto that, which surpasses all things as such (that is, the one, true, and best God, without whom no nature subsists, no doctrine instructs, no exercise liberates), then may he be sought, in whom for us all things are serene; may he be discerned, in whom for us all things are certain; may he be loved, in whom for us all things are right."

"If, therefore", as Augustine says in chapter 5, "Plato declared that the wise person is the one who imitates, knows, and loves this God, and becomes blessed by participating in him", what remains to be said, except that the end of theological wisdom is God? And what could be signified by those two letters on Philosophy's garment, except activity and knowledge?

And so Avicebron, in Book I of the Fount of Life, chapter 2, ${ }^{106}$ responds to the question, "What is it that the human ought to seek in this life?", and says: "Since the part of the human that knows is better than all other parts, then the higher activity is to seek knowledge. As for knowledge, however, it is more necessary that he know himself, so that through this he might know things that are outside him; for his essence comprehends and penetrates all things, and all things are subjected to his power. Along with this, he should also seek knowledge of the final cause, on account of which he was made, so that he might seek it out more zealously, because happiness will follow on account of this." And later, in the character of the Disciple:107 "What, therefore, is the final cause for which the human was made? Master: To join himself to the higher world, so that each thing might return to what is similar to it." And later:108 "Knowledge

105 Cf. Augustine, De civitate Dei, viII.4-5, p. 220, l. 33-38 and p. 220, l. 56 - p. 221, l. 2; cf. Thomas of York, Sapientiale, lib. I, c. 16 (F f. 2ora).

106 Avicebron, Fons vitae, lib. I, c. 2, p. 4, l. 1-9.

107 Avicebron, Fons vitae, lib. I, c. 2, p. 4, l. 23-25; cf. Thomas of York, Sapientiale, lib. I, c. 1 (F f. iva).

108 Avicebron, Fons vitae, lib. I, c. 2, p. 5, l. 2-4. 
and activity liberate the soul altogether from the captivity of nature and purge it of its darkness and obscurity; in this way, the soul returns to its higher world." And later, in chapter 4:109 "The knowledge, for which the human being was created, is the knowledge of all things insofar as they exist and is, above all, the knowledge of the first Essence, which sustains and moves them", in order that the soul may be joined to the higher world.

Boethius sings of this world in Book III of On the Consolation, metre 9:110

From the supernal exemplar

You lead all things out, you who are most beautiful; the beautiful world You carry in your mind.

From all the foregoing it is abundantly clear that, not only through activity and knowledge, as through the two letters, the practical and theoretical, but even more so through the highest philosophy of the Theological Elementation, a person returns by an ascent to his final perfection, for the sake of which he was created: namely, happiness or, to speak more plainly, beatitude. "For there is no reason for a person to philosophise except that he may be blessed", according to Augustine in Book XIX of On the City of God, chapter 2, ${ }^{111}$ "but what makes him blessed is the End of all good; therefore, there is no reason to philosophise, except the End of all good": "for the End of all good, as soon as anyone arrives to it, immediately makes him blessed".112

Now, what is the end of all good but the highest Good, the Good that is "the Good of every good"?113

To the knowledge of this Good this entire book is arranged, since it makes us ascend through the good participants in the divine Good, to knowledge of the divine goods according to essence. And that we may ascend through this to contemplate the highest Good, the primarily Good, may we be carried across with his support, who is the mediator of God and humanity, Jesus Christ, ${ }^{114}$ who with the Father and the Holy Spirit lives and reigns, one God, unto the ages of ages. Amen.

\footnotetext{
109 Avicebron, Fons vitae, lib. I, c. 4, p. 6, 1. 13-15.

110 Boethius, Consolatio philosophiae, lib. III, metrum 9, p. 8o, l. 6-8.

111 Augustine, De civitate Dei, XIX.1, p. 659, 1.121-123.

112 Augustine, De civitate Dei, XIX.2, p. 66。, 1. 8-9.

113 Augustine, De Trinitate, viII.3.4, p. 272, 1. 17.

114 Cf. 1 Timothy 2:5.
} 